\title{
Comparison of Separation of Manual and Rotary Files during Endodontic Treatment: A KAP Survey
}

\author{
Talha M Siddiqui, Aisha Wali, Junaid Tariq, Hafsa Ghauri
}

\begin{abstract}
OBJECTIVE: To determine the frequency of manual and rotary instrument separation during endodontic treatment amongst experienced dental practitioners and house surgeons.

METHODOLOGY: The present study was conducted in various dental teaching hospitals registered with Pakistan Medical and Dental Council (PMDC) from July 2018 to January 2019. The sample size calculation was obtained by taking $50 \%$ prevalence rate using Open EPI software (version 3.01) at 95\% confidence interval and $\alpha=5 \%$ and was calculated to be 250 . A self-administered questionnaire containing 22 closed ended questions was designed to evaluate different reasons of separation of manual and rotary endodontic instruments amongst experienced dental practitioners and house surgeons.

RESULTS: A total of 250 participants were included in this study, out of them 192 were house officers and 58 were dental practitioners.122 (63.5\%) of the house surgeons and $30(51.7 \%)$ of dental practitioners experienced instruments breakage during root canal treatment. When the types of files were assessed, the results showed that the separation of $\mathrm{K}$ - files was most frequent than $\mathrm{H}$-files and $\mathrm{Ni}$-Ti rotary files.106(55.2\%) of the house surgeons and $23(39.7 \%)$ of the dental practitioners reported separation of K-files during root canal treatment.

CONCLUSION: The present study concluded that majority of the house surgeons experienced K-file separation than $\mathrm{H}$-file and $\mathrm{Ni}$-Ti rotary files than Dental practitioners during root canal treatment.
\end{abstract}

KEYWORDS: Endodontic instruments, File fracture, Instrument separation, Mishaps.

This article may be cited as: Siddiqui TM, Wali A, Tariq J, Ghauri H. Comparison of Separation of Manual and Rotary Files during Endodontic Treatment: A KAP Survey. J Liaquat Uni Med Health Sci. 2019;18(04):314-8. doi: 10.22442/jlumhs.191840649

\section{INTRODUCTION}

Separation of Endodontic instruments is considered to be one of the most troublesome hazards ${ }^{1-3}$ that compromises endodontic treatment and might impact on the prognosis ${ }^{4}$. Fracture of the instruments is caused by incorrect movements of the instruments or by the use of deformed instruments that have lost their capacity of performing the procedure ${ }^{5,6}$. The endodontic treatment is dependent on the quality of the cleaning and shaping of the root canal system and during these procedures, the risk of separation of an instrument occurs mostly due to negligence of theoperator ${ }^{7,8}$. The conventional approach to endodontic treatment implicates the use of stainless steel hand files of predetermined diameters and taper $^{9}$. Root canal treatment has been plagued with a relatively high possibility of procedural mishaps ${ }^{10}$ such as perforations, ledge formation, overfills, underfills, instrument separations ${ }^{10-12}$. Recently it has been reported that nickel-titanium $(\mathrm{Ni}-\mathrm{Ti})$ rotary instruments used for root canal treatment enhanced the skills to prepare root canals effectively and efficiently ${ }^{13}$.

Separation rates of rotary $\mathrm{Ni}-\mathrm{Ti}$ instruments reported between the range of $1.3 \%$ and $10.0 \%$, whereas separation rates of stainless steel instruments were ranged between $0.25 \%$ and $6^{13-19}$. The reason of this higher frequency of instrument separation reported might be because of slight standardization in terms of techniques used, operator skills and experience, position of the tooth and curvature of the root ${ }^{5,14,16,17,20-23}$. Separation of endodontic instruments in many circumstances resulted from incorrect or overuse of an endodontic instrument ${ }^{24}$. Files with a rotational speed of $350 \mathrm{rpm}$ were more likely to get separated than those with $250 \mathrm{rpm}$ and 150rpm. Decreased angle of curvature of the root canal significantly reduces the likelihood of instrument separation ${ }^{25}$. During root canal treatment, separation of endodontic instruments often leads the operator to a state of frustration and anxiety initially and later develop a state of confusion about treatment and its prognosis ${ }^{26}$. Bortnick KL2001 ${ }^{27}$ reported that there was no difference in the file separation when hand- and rotary instruments were compared. Panitvisai P $2010^{5}$ reported that the distortion of rotary instruments was mostly operator related. The rationale of the present study was to assess the frequency of separation of manual and rotary files during root canal treatment performed by house surgeons and experienced Dental Practitioners. 
The aim of this current study was to determine the frequency of manual and rotary instrument separation during endodontic treatment amongst experienced dental practitioners and house surgeons.

\section{METHODOLOGY}

The present study was conducted in private dental colleges registered with Pakistan Medical and Dental Council (PMDC) from July 2018-January 2019. The study was approved by the Research Department and ethical approval was given by the ethical committee, Baqai Dental College, Baqai Medical University. A self -administered questionnaire containing 22 closed ended questions was designed to evaluate different reasons of separation of manual and rotary endodontic instruments amongst experienced dental practitioners and house surgeons. A pilot study was conducted on 20 participants to assess the reliability of the questionnaire with Cronbach's alpha score of 0.6 . The sample size calculation was obtained by taking $50 \%$ prevalence rate using Open EPI (version 3.01 ) at $95 \%$ confidence interval and $\alpha=5 \%$ and was calculated to be 250 . The house surgeons who had completed their two months rotation in Endodontic Department and experienced dental practitioners from various dental teaching hospitals of Karachi were included in the study. Questionnaires were to the participants of the dental colleges and were collected the next day. All the participants were instructed that questionnaires must be filled completely. Data was analyzed for descriptive analysis (frequency and percentages). Chi-square test was applied to compare frequency of instrument breakage amongst house surgeons and Dental Practitioners by using IBM SPSS software version 22. P-value was set at 0.05 .

\section{RESULTS}

A total of 250 participants were included in this study, out of them 192 were house surgeons and 58 were dental practitioners. (Figure I).

\section{FIGURE I: DISTRIBUTION OF PARTICIPANTS}

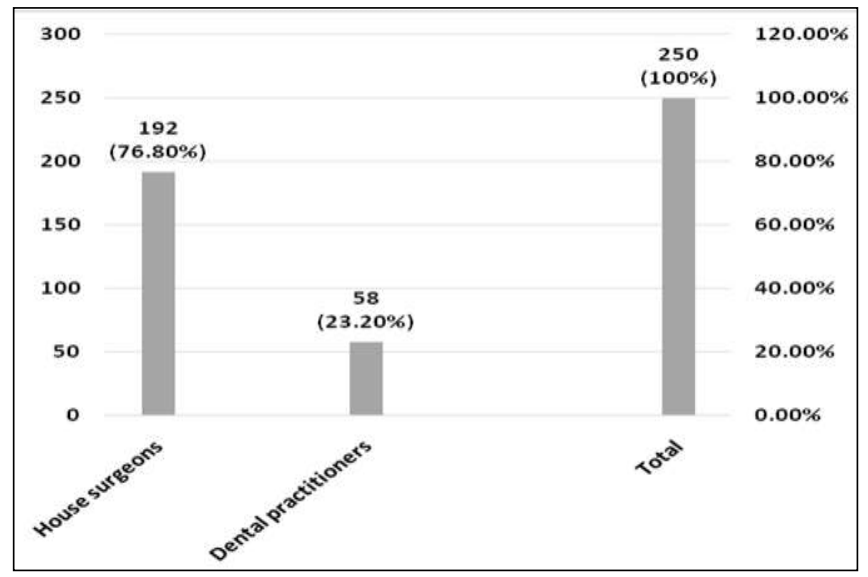

One hundred and twenty two $(63.5 \%)$ house surgeons and $30(51.7 \%)$ of dental practitioners experienced instruments breakage during root canal treatment. Separation of manual instruments during root canal treatment was reported by $109(56.8 \%)$ of house surgeons and $28(48.3 \%)$ of dental practitioners. When the types of files were assessed, the results showed that the separation of $\mathrm{K}$ - files was the most frequent than $\mathrm{H}$-files and $\mathrm{Ni}$ - $\mathrm{Ti}$ rotary files, $106(55.2 \%)$ of the house surgeons and $23(39.7 \%)$ of the dental practitioners reported separation of K-files during root canal treatment (Table I).

Question regarding taking radiograph after separation of instruments, $133(69.3 \%)$ of the house surgeons and $42(72.4 \%)$ of dental practitioners responded that they took radiographs after instrument separation. The most common area of instrument separation was the apical area. 116(60.4\%) of the house surgeons and $33(56.9 \%)$ of the dental practitioners reported that their instrument separated in the apical area (Table II). One hundred and twenty $(62.5 \%)$ of the house surgeons and $33(56.9 \%)$ of dental practitioners reported that they were using old instrument during root canal treatment (Table III).

$90(46.9 \%)$ of the house surgeons and $34(58.6 \%)$ of dental practitioners reported that they discard their instrument when appears shiny (Table IV).

\section{TABLE I: FREQUENCY OF MANUAL AND ROTARY INSTRUMENT SEPARATION}

\begin{tabular}{|c|c|c|c|}
\hline Variables & $\begin{array}{l}\text { House } \\
\text { surgeons }\end{array}$ & $\begin{array}{c}\text { Dental Prac- } \\
\text { titioners }\end{array}$ & $p$-value \\
\hline $\begin{array}{l}\text { Did you experience } \\
\text { any incident of } \\
\text { instrument } \\
\text { breakage? }\end{array}$ & $\begin{array}{l}\text { Yes } 122(63.5 \%) \\
\text { No } 70(36.5 \%)\end{array}$ & $\begin{array}{l}\text { Yes } 30(51.7 \%) \\
\text { No } 28(48.3 \%)\end{array}$ & 0.10 \\
\hline $\begin{array}{l}\text { Did you experience } \\
\text { breakage of } \\
\text { manual } \\
\text { instruments? }\end{array}$ & $\begin{array}{l}\text { Yes } 109(56.8 \%) \\
\text { No } 83(43.2 \%)\end{array}$ & $\begin{array}{l}\text { Yes } 28(48.3 \%) \\
\text { No } 30(51.7 \%)\end{array}$ & 0.16 \\
\hline $\begin{array}{l}\text { Are K files mostly } \\
\text { fractured? }\end{array}$ & $\begin{array}{l}\text { Yes } 106(55.2 \%) \\
\text { No } 86(44.8 \%)\end{array}$ & $\begin{array}{l}\text { Yes } 23(39.7 \%) \\
\text { No } 35(60.3 \%)\end{array}$ & 0.02 \\
\hline $\begin{array}{l}\text { Are } \mathrm{H} \text { files mostly } \\
\text { fractured? }\end{array}$ & $\begin{array}{l}\text { Yes } 73(38 \%) \\
\text { No } 119(62 \%)\end{array}$ & $\begin{array}{l}\text { Yes } 26(44.8 \%) \\
\text { No } 32(55.2 \%)\end{array}$ & 0.33 \\
\hline $\begin{array}{l}\text { Are Nickel Tita- } \\
\text { nium rotary files } \\
\text { mostly fractured? }\end{array}$ & $\begin{array}{l}\text { Yes } 86(44.8 \%) \\
\text { No } 106(55.2 \%)\end{array}$ & $\begin{array}{l}\text { Yes } 13(22.4 \%) \\
\text { No } 45(77.6 \%)\end{array}$ & 0.002 \\
\hline
\end{tabular}


Talha M Siddiqui, Aisha Wali, Junaid Tariq, Hafsa Ghauri

\section{TABLE II: SEPARATION OF MANUAL AND ROTARY INSTRUMENTS ACCORDING TO FREQUENCY OF BREAKAGE AREA}

\begin{tabular}{|c|c|c|c|}
\hline Variables & $\begin{array}{l}\text { House } \\
\text { surgeons }\end{array}$ & $\begin{array}{c}\text { Dental Prac- } \\
\text { titioners }\end{array}$ & p-value \\
\hline $\begin{array}{l}\text { Did you take any } \\
\text { radiograph after } \\
\text { breaking the } \\
\text { instrument? }\end{array}$ & $\begin{array}{l}\text { Yes } 133(69.3 \%) \\
\text { No } 59(30.7 \%)\end{array}$ & $\begin{array}{l}\text { Yes } 42(72.4 \%) \\
\text { No } 16(27.6 \%)\end{array}$ & 0.70 \\
\hline $\begin{array}{l}\text { Did the instrument } \\
\text { break in apical } \\
\text { area? }\end{array}$ & $\begin{array}{l}\text { Yes } 116(60.4 \%) \\
\text { No } 76(39.6 \%)\end{array}$ & \begin{tabular}{|l} 
Yes $33(56.9 \%)$ \\
No $25(43.1 \%)$
\end{tabular} & 0.63 \\
\hline $\begin{array}{l}\text { Did the instrument } \\
\text { break in middle } \\
\text { area? }\end{array}$ & $\begin{array}{l}\text { Yes } 57(29.7 \%) \\
\text { No } 135(70.3 \%)\end{array}$ & \begin{tabular}{|l|} 
Yes 23 \\
$(39.7 \%)$ \\
No $35(60.3 \%)$
\end{tabular} & 0.15 \\
\hline $\begin{array}{l}\text { Is the frequency of } \\
\text { breaking instru- } \\
\text { ments } 5 \% \text { ? }\end{array}$ & $\begin{array}{l}\text { Yes } 80(41.7 \%) \\
\text { No } 112(58.3 \%)\end{array}$ & $\begin{array}{l}\text { Yes } 27(46.6 \%) \\
\text { No } 31(53.4 \%)\end{array}$ & 0.51 \\
\hline $\begin{array}{l}\text { Is the frequency of } \\
\text { breaking instru- } \\
\text { ments } 15 \% ?\end{array}$ & $\begin{array}{l}\text { Yes } 91(47.4 \%) \\
\text { No } 101(52.6 \%)\end{array}$ & \begin{tabular}{|l|} 
Yes $20(34.5 \%)$ \\
No $38(65.5 \%)$
\end{tabular} & 0.08 \\
\hline $\begin{array}{l}\text { Is the frequency of } \\
\text { breaking instru- } \\
\text { ments } 25 \% \text { ? }\end{array}$ & $\begin{array}{l}\text { Yes } 57(29.7 \%) \\
\text { No } 135(70.3 \%)\end{array}$ & \begin{tabular}{|l|} 
Yes $14(24.1 \%)$ \\
No $44(75.9 \%)$
\end{tabular} & 0.41 \\
\hline
\end{tabular}

TABLE III: QUALITY OF ENDODONTIC INSTRUMENTS AND CANAL CONFIGURATION

\begin{tabular}{|c|c|c|c|}
\hline Variables & $\begin{array}{l}\text { House } \\
\text { surgeons }\end{array}$ & $\begin{array}{c}\text { Dental Prac- } \\
\text { titioners }\end{array}$ & p-value \\
\hline $\begin{array}{l}\text { Do you re-use the } \\
\text { instrument? }\end{array}$ & $\begin{array}{l}\text { Yes } 120(62.5 \%) \\
\text { No } 72(37.5 \%)\end{array}$ & $\begin{array}{l}\text { Yes } 33(56.9 \%) \\
\text { No } 25(43.1 \%)\end{array}$ & 0.44 \\
\hline $\begin{array}{l}\text { Do you think re- } \\
\text { usable instruments } \\
\text { are more prone to } \\
\text { fracture? }\end{array}$ & $\begin{array}{l}\text { Yes } 166(86.5 \%) \\
\text { No } 26(13.5 \%)\end{array}$ & $\begin{array}{l}\text { Yes } 51(87.9 \%) \\
\text { No } 7(12.1 \%)\end{array}$ & 0.77 \\
\hline $\begin{array}{l}\text { Do you think in- } \\
\text { struments handling } \\
\text { technique can } \\
\text { cause its fracture? }\end{array}$ & $\begin{array}{l}\text { Yes } 164(85.4 \%) \\
\text { No } 28(14.6 \%)\end{array}$ & $\begin{array}{l}\text { Yes } 54(93.1 \%) \\
\text { No } 4(6.9 \%)\end{array}$ & 0.12 \\
\hline $\begin{array}{l}\text { Do you think } \\
\text { mostly instruments } \\
\text { are broken during } \\
\text { initial visit? }\end{array}$ & $\begin{array}{l}\text { Yes } 121(63 \%) \\
\text { No } 71(37 \%)\end{array}$ & $\begin{array}{l}\text { Yes } 35(60.3 \%) \\
\text { No } 23(39.7 \%)\end{array}$ & 0.71 \\
\hline $\begin{array}{l}\text { Do you think canal } \\
\text { configuration has } \\
\text { something to do } \\
\text { with instrument } \\
\text { breakage? }\end{array}$ & $\begin{array}{l}\text { Yes } 148(77.1 \%) \\
\text { No } 44(22.9 \%)\end{array}$ & $\begin{array}{l}\text { Yes } 46(79.3 \%) \\
\text { No } 12(20.7 \%)\end{array}$ & 0.72 \\
\hline $\begin{array}{l}\text { Can you recognize } \\
\text { when to stop using } \\
\text { the instrument? }\end{array}$ & $\begin{array}{l}\text { Yes } 138(71.9 \%) \\
\text { No } 54(28.1 \%)\end{array}$ & $\begin{array}{l}\text { Yes } 48(82.8 \%) \\
\text { No } 10(17.2 \%)\end{array}$ & 0.09 \\
\hline
\end{tabular}

\section{DISCUSSION}

A successful root canal treatment depends upon proper root canal cleaning and shaping without any
TABLE IV: DECISIONS REGARDING DISCARDING OF ENDODONTIC INSTRUMENT

\begin{tabular}{|c|c|c|c|}
\hline Variables & $\begin{array}{l}\text { House } \\
\text { surgeons }\end{array}$ & $\begin{array}{c}\text { Dental Prac- } \\
\text { titioners }\end{array}$ & p-value \\
\hline $\begin{array}{l}\text { Do you think use of } \\
\text { lubrication can } \\
\text { reduce the chance } \\
\text { of instrument } \\
\text { breakage? }\end{array}$ & $\begin{array}{l}\text { Yes } 145(75.5 \%) \\
\text { No } 47(24.5 \%)\end{array}$ & $\begin{array}{l}\text { Yes } 48(82.8 \%) \\
\text { No } 10(17.2 \%)\end{array}$ & 0.25 \\
\hline $\begin{array}{l}\text { Do you discard } \\
\text { your instrument } \\
\text { when it shows } \\
\text { shiny appearance? }\end{array}$ & $\begin{array}{l}\text { Yes } 90(46.9 \%) \\
\text { No } 102(53.1 \%)\end{array}$ & $\begin{array}{l}\text { Yes } 34(58.6 \%) \\
\text { No } 24(41.4 \%)\end{array}$ & 0.11 \\
\hline $\begin{array}{l}\text { Do you discard } \\
\text { your instrument } \\
\text { when distance } \\
\text { between its flutes } \\
\text { increases? }\end{array}$ & $\begin{array}{l}\text { Yes } 141(73.4 \%) \\
\text { No } 51(26.6 \%)\end{array}$ & $\begin{array}{l}\text { Yes } 48(82.8 \%) \\
\text { No } 10(17.2 \%)\end{array}$ & 0.14 \\
\hline $\begin{array}{l}\text { Do you discard } \\
\text { your instruments } \\
\text { when it has sharp } \\
\text { bends? }\end{array}$ & $\begin{array}{l}\text { Yes } 166(86.5 \%) \\
\text { No } 26(13.5 \%)\end{array}$ & $\begin{array}{l}\text { Yes } 53(91.4 \%) \\
\text { No } 5(8.6 \%)\end{array}$ & 0.31 \\
\hline
\end{tabular}

endodontic mishaps such as separation of manual and rotary files. To minimize these mishaps, the operators should establish the methods for proper usage of $\mathrm{Ni}-\mathrm{Ti}$ files which is based on the information attained from continuing medical education courses or articles reporting survey data ${ }^{28-31}$. The present study reported that majority of the house surgeons and dental practitioners experienced separation of manual and rotary endodontic instruments during root canal treatment. Pedir SS $2016^{32}$ in a study reported dissimilar results when asked about incident of instrument breakage. Mozayeni MA $2011^{33}$ in a study reported that majority of the general practitioners broke $\mathrm{Ni}$-Ti files than hand files during root canal treatment. Lee W $2012^{34}$ in a study reported that $54.6 \%$ of the respondents experienced file separation during root canal treatment. Alrahabi M $2015^{35}$ reported instrument separation of $5.56 \%$ of $\mathrm{Ni}-\mathrm{Ti}$ instruments corresponding only $1.1 \%$ of stainless steel instruments. Sonntag $2003^{36}$ in a study reported that $\mathrm{Ni}-\mathrm{Ti}$ instruments were more prone to fracture when compared with their stainless steel instruments. The reason of instrument separation is due to cyclic fatigue of the rotary instruments on repeated usage ${ }^{37}$. Stainless steel files are more resilient to fracture and easily identifiable signs included visible unwinding of flutes, tip distortion, roll-up of flutes and corrosion prior to separation ${ }^{38}$.

Pedir SS $2016^{32}$ in a study reported that higher percentage of separation cases with dental practitioners and students were of stainless steel hand files followed by Ni-Ti rotary files. Andrabi SM $2013^{39}$ reported that the incidence of instrument separation 
has increased with the increased use of $\mathrm{Ni}-\mathrm{Ti}$ instruments hand or rotary. Simon $S 2008^{40}$ reported that $\mathrm{Ni}-\mathrm{Ti}$ instruments are not brittle than a stainless steel instrument of equivalent size.

The preparation techniques were related to the frequency of file separation ${ }^{28}$. Experienced dental Practitioners perform cleaning and shaping of the root canal by using different file systems and different preparation techniques to avoid procedural mishaps ${ }^{28}$. It is also recommended that $\mathrm{Ni}-\mathrm{Ti}$ rotary instruments should be thrown away after single use which is ideal for reducing the risk of file separation; however, the increased cost of $\mathrm{Ni}-\mathrm{Ti}$ files has forced dental practitioners to reuse them ${ }^{28}$. The frequency of reusing $\mathrm{Ni}-\mathrm{Ti}$ files differed according to experience and therefore experienced dental practitioners had a strong tendency of reusing the files 6-10 times. This happened due to the experience based opinion that a file can be safely re- used more and it seemed that experienced dental practitioners do not rush through a procedure, so that it could decrease the chance of torsional failure ${ }^{41,42}$. This study reported that 120 $(62.5 \%)$ of the house surgeons and $33(56.9 \%)$ of dental practitioners reported re-use of instrument during root canal treatment.

Instrument separation was 33.5 times more likely to occur in the apical one third than the coronal one third of the tooth ${ }^{17}$. The present study reported that majority of the house surgeons and the dental Practitioners broke instrument in the apical area. Patil TN $2017^{43}$ in a study reported similar results that the Dental Practitioners most commonly broke instrument in apical one third area.

The incidence of file separation decreases with the canal irrigation protocol and with controlled speed and torque of the hand piece. The gel form of a lubricant was the main factor to influence mechanical stresses on instruments and therefore aqueous solutions were superior to gel type preparation. Furthermore, the addition of a chelating agent caused some further decrease in torque, torsional load, and force values and this effect worked immediately ${ }^{44}$. This present study reported that majority of the house surgeons and the dental practitioners used lubricant to reduce chances of file separation during root canal treatment. Patil TN $2017^{43}$ in a study reported similar results that irrigation/ lubrication of the instrument decreases the file separation.

Endodontic instruments should be checked before being introduced into a root canal to make sure that the spirals are regularly aligned and if the blades are not spaced equally, it is an indication that the instrument has been strained and that the torque has caused the blades to become irregularly spaced. A quick glance is sufficient to determine whether the instrument has been strained and should be discarded ${ }^{45}$. The present study reported that most of the house surgeons and the dental practitioners discarded the instruments when it has sharp bends or when distance between flutes increased.

Patil TN $2017^{43}$ in a study reported similar results that the dental practitioners discarded files after repeated re-use.

Strength of the present study is that it is one of the studies that emphasized only on manual and rotary file separation during root canal treatment performed by house surgeons and experienced house surgeons from different dental colleges. The study has limitations that include the small sample size, limited dental teaching hospitals.

\section{CONCLUSION}

Frequency of instrument breakage was reported to be high amongst house surgeons when compared to Dental practitioners and this is due to that they do more cases than house surgeons. Majority of the house surgeons reported experience of breakage of manual instruments than rotary instruments.

Ethical permission: Baqai Dental College Karachi, ERC approval letter Dated: 03-01-2019.

Conflict of interest: Authors of the study have no conflict of interest to declare.

Funding: There was no any funding agency.

\section{REFERENCES}

1. Shen $Y$, Haapasalo M, Cheung GS, Peng B. Defects in nickel-titanium instruments after clinical use. Part 1: Relationship between observed imperfections and factors leading to such defects in a cohort study. J Endod. 2009; 35(1): 129-32. doi:10.1016/j.joen.2008.10.014.

2. Shen $Y$, Coil JM, McLean AG, Hemerling DL, Haapasalo $M$. Defects in nickel-titanium instruments after clinical use. Part 5: Single use from endodontic specialty practices. J Endod. 2009; 35 (10): 1363-7. doi:10.1016/j.joen.2009.07.004.

3. Shen Y, Coil JM, Haapasalo M. Defects in nickel titanium instruments after clinical use. Part 3: A 4year retrospective study from an undergraduate clinic. J Endod. 2009; 35(2): 193-6. doi:10.1016/ j.joen.2008.11.003.

4. Panitvisai $P$, Parunnit $P$, Sathorn $C$, Messer $\mathrm{HH}$. Impact of a retained instrument on treatment outcome: a systematic review and meta-analysis. J Endod. 2010; 36(5): 775-80.

5. Parashos P, Gordon I, Messer HH. Factors influencing defects of rotary nickel-titanium endodontic instruments after clinical use. J Endod. 2004; 30(10): 722-5.

6. Grossman LI. Guidelines for the prevention of 
fracture of root canal instruments. Oral Surg Oral Med Oral Pathol. 1969; 28(5): 746-52. doi:10.1016/0030-4220(69)90423-X.

7. Sjogren U, Hagglund B, Sundqvist G, Wing K. Factors affecting the long-term results of endodontic treatment. J Endod. 1990; 16(10): 498-504.

8. Siqueira Jr JF. Aetiology of root canal treatment failure: why well-treated teeth can fail. Int Endod J. 2001; 34(1): 1-10.

9. Smith CS, Setchell DJ, Harty FJ. Factors influencing the success of conventional root canal therapy--a five-year retro-spective study. Int Endod J. 1993; 26(6): 321-33.

10. Cheung GS, Liu CS. A Retrospective Study of Endodontic Treatment Outcome between Nickel-Titanium Rotary and Stainless Steel Hand Filing Techniques. J Endod. 2009; 35(7): 938-43. doi:10.1016/j.joen.2009.04.016.

11. Chen JL, Messer HH. A Comparison of Stainless Steel Hand and Rotary Nickel-Titanium Instrumentation Using a Silicone Impression Technique. Aust Dent J. 2002; 47(1): 12-20.

12. Himel VT, Ahmed KM, Wood DM, Alhadainy HA. An evalua-tion of nitinol and stainless steel files used by dental students during a laboratory proficiency exam. Oral Surg Oral Med Oral Pathol Oral Radiol Endod. 1995; 79(2): 232-7.

13. Iqbal MK, Maggiore F, Suh B, Edwards KR, Kang $\mathrm{J}$, Kim S. Comparison of apical transportation in four $\mathrm{Ni}-\mathrm{Ti}$ rotary instrumentation techniques. J Endod. 2003; 29(9): 587-91.

14. Spili $P$, Parashos $P$, Messer $\mathrm{HH}$. The impact of instrument fracture on outcome of endodontic treatment. J Endod. 2005; 31(12): 845-50.

15. Knowles KI, Hammond NB, Biggs SG, Ibarrola JL. Incidence of instrument separation using LightSpeed rotary instruments. J Endod. 2006; 32 (1): 14-6.

16. Wolcott S, Wolcott J, Ishley D, Kennedy W, Johnson S, Minnich S, et al. Separation incidence of protaper rotary instruments: A large cohort clinical evaluation. J Endod. 2006; 32(12): 1139-41.

17. Iqbal MK, Kohli MR, Kim JS. A retrospective clinical study of incidence of root canal instrument separation in an endodontics graduate program: A PennEndo database study. J Endod. 2006; 32 (11): 1048-52.

18. Khan M, Rehman K, Saleem M. Causes of endodontic treatment failure--A study. Pak Oral Dent J. 2010; 30(1): 232-36.

19. Yousuf W, Khan M, Mehdi H. Endodontic procedural errors: frequency, type of error, and the most frequently treated tooth. Int J Dent. 2015; 673914: 1-7. doi:10.1155/2015/673914

20. Cheung GS. Instrument fracture: mechanisms, removal of fragments, and clinical outcomes. Endod Topics. 2009; 16(1): 1-26. doi:10.1111/ j.1601-1546.2009.00239.x.

21. Alapati SB, Brantley WA, Svec TA, Powers JM, Mitchell JC. Scanning electron microscopy observa-tions of new and used nickel-titanium rotary files. J Endod. 2003; 29(10): 667-9.

22. Pettiette MT, Connor D, Trope M. Procedural errors with the use of nickel-titanium rotary instruments in undergraduate endodontics. J Endod. 2002; 28(3): 259.

23. Ruddle CJ. Nonsurgical retreatment. J Endod. 2004; 30(12): 827-45.

24. Parashos $\mathrm{P}$, Messer $\mathrm{HH}$. Rotary NiTi instrument fracture and its consequences. J Endod 2006; 32 (11): 1031-43.

25. Martin B, Zelada G, Varela P, Bahillo JG, Magan $F$, Ahn S, et al . Factors influencing the fracture of nickel-titanium rotary instruments. Int Endod J. 2003; 36(4): 262-6.

26. Rambabu T. Management of Fractured Endodontic Instruments in Root Canal: A Review. J Sci Dent. 2014; 4(2): 40-48.

27. Bortnick KL, Steiman HR, Ruskin A. Comparison of nickel-titanium file distortion using electric and air-driven handpieces. J Endod. 2001; 27(1): 57-9.

28. Lee M, Winkler J, Hartwell G, Stewart J, Caine R. Current trends in endodontic practice: emergency treatments and technological armamentarium. J Endod. 2009; 35(1): 35-9.

29. Bird DC, Chambers D, Peters OA. Usage parameters of nickel-titanium rotary instruments: a survey of endodontists in the United States. J Endod. 2009; 35(9): 1193-7. doi: 10.1016/j.joen. 2009.05.027.

30. Madarati AA, Watts DC, Qualtrough AJ. Opinions and attitudes of endodontists and general dental practitioners in the UK towards the intracanal fracture of endodontic instruments: part 1. Int Endod J. 2008; 41(8): 693-701. doi:10.1111/ j.1365-2591.2008.01425.x.

31. Parashos P, Messer HH. Questionnaire survey on the use of rotary nickel-titanium endodontic instruments by Australian dentists. Int Endod J. 2004; 37(4): 249-59.

32. Pedir SS, Mahran AH, Beshr K, Baroudi K. Evaluation of the Factors and Treatment Options of Separated Endodontic Files among dentists and undergraduate students in Riyadh area. J Clin Diag Res. 2016; 10(3): ZC18-ZC23. doi:10.7860/ JCDR/2016/ 16785.7353.

33. Mozayeni MA, Golshah A, Nik Kerdar N. A Survey on $\mathrm{NiTi}$ Rotary Instruments Usage by Endodontists and General Dentist in Tehran. Iran Endod J. 2011; 6(4): 168-75. 
34. Lee W, Song M, Kim E, Lee H, Kim HC. A survey of experience-based preference of NickelTitanium rotary files and incidence of fracture among general dentists. Restor Dent Endod. 2012; 37(4): 201-6. doi:10.5395/rde.2012.37. 4.201.

35. Alrahabi M. Comparative study of root-canal shaping with stainless steel and rotary NiTi files performed by preclinical dental students. Technol Health Care. 2015; 23(3): 257-65. doi:10.3233/ THC-150895.

36. Sonntag, Delschen S, Stachniss V. Root-canal shaping with manual and rotary $\mathrm{Ni}-\mathrm{Ti}$ files performed by students. Int Endod J 2003; 36(11): 715-23.

37. Pruett JP, Clement DJ, Carnes DL, Jr. Cyclic fatigue testing of nickel-titanium endodontic instruments. J Endod 1997; 23(2): 77-85.

38. Walton RE, Torabinejad M. Principles and practice of endodontics. 3rd ed. Philadelphia: W.B. Saunders Company; 2002. Pg 159.

39. Andrabi SM, Kumar A, Iftekhar H, Alam S. Retrieval of a separated nickel-titanium instrument using a modified 18-guage needle and cyanoacry- late glue: a case report. Restor Dent Endod. 2013; 38(2): 93-7. doi:10.5395/rde.2013.38.2.93.

40. Simon S, Machtou P, Tomson P, Adams N, Lumley $P$. Influence of fractured instruments on the success rate of endodontic treatment. Dent Update. 2008; 35(2): 172-4, 176, 178-9.

41. Roland DD, Andelin WE, Browning DF, Hsu GH, Torabinejad $M$. The effect of preflaring on the rates of separation for 0.04 taper nickel titanium rotary instruments. J Endod. 2002; 28(7): 543-45.

42. Sattapan B, Nerco GJ, Palamara JE, Messer HH. Defects in rotary nickel-titanium files after clinical use. J Endod. 2000; 26: 161-5.

43. Patil TN, Saraf PA, Raghavendra P, Vanaki S, Kamatagi L. A Survey on Nickel Titanium Rotary Instruments and their Usage Techniques by Endodontists in India. J Clin Diagn Res. 2017; 11(5): ZC29-ZC35. doi:10.7860/JCDR/2017/23936.9852.

44. Boessler C, Peters OA, Zehnder M. Impact of lubricant parameters on rotary instrument torque and force. J Endod. 2007; 33(3): 280-83.

45. Grossman LI. Guidelines for the prevention of fracture of root canal instruments. Oral Surg Oral Med Oral Pathol. 1969; 28(5): 746-52.

\begin{tabular}{|l|}
\hline AUTHOR AFFILIATION: \\
Dr. Talha M Siddiqui \\
Associate Professor \\
Department of Operative Dentistry \\
Baqai Dental College, Karachi, Sindh-Pakistan. \\
Dr. Aisha Wali (Corresponding Author) \\
Assistant Director Research \\
Department of Research and Medical Education \\
Baqai Dental College, BMU \\
51 - Dehtor Superhighway Near Toll Plaza \\
Karachi, Sindh-Pakistan. \\
Email: aishawali@hotmail.com \\
Dr. Junaid Tariq \\
House Surgeon \\
Department of Operative Dentistry \\
Baqai Dental College, BMU \\
Karachi, Sindh-Pakistan. \\
Dr. Hafsa Ghauri \\
House Surgeon \\
Department of Operative Dentistry \\
Baqai Dental College, BMU \\
Karachi, Sindh-Pakistan.
\end{tabular}

